\title{
ANALISIS SISTEM INFORMASI PENGELOLAAN DATA ALUMNI BERBASIS CODEIGNITER PHP FRAMEWORK
}

\author{
Alcianno G. Gani \\ localghost@gmail.com
}

\begin{abstract}
Data management of alumni who still use the printed document means that data management can not be done quickly and there are still frequent errors and difficult to update. This problem can be overcome with a method that is developing the programming system. One of them with software. With this information management system software is expected to help the data management of alumni. Furthermore, the information management system software is expected to produce the information needed effectively and efficiently when in making decisions in managing human resources coming from the alumni. In order to be able to establish fellow alumni relationships for the better.
\end{abstract}

Keywords: alumni data, web application, codeigniter

\section{PENDAHULUAN}

Pengelolaan data alumni yang masih menggunakan cara dokumen cetak, mengakibatkan pengelolaan data belum dapat dilakukan dengan cepat dan masih sering terjadi kesalahan serta sulit untuk diperbarui. Permasalahan ini dapat ditanggulangi dengan suatu metode yang sedang berkembang yaitu sistem pemrograman. Salah satunya dengan perangkat lunak.

Dengan perangkat lunak sistem manajemen informasi ini diharapkan dapat membantu pengelolaan data alumni. Selanjutnya, perangkat lunak sistem manajemen informasi ini diharapkan dapat menghasilkan informasi yang dibutuhkan secara efektif dan efisien ketika dalam pengambilan keputusan dalam mengelola sumber daya manusia yang berasal dari alumni. Agar dapat terjalin hubungan sesama alumni menjadi lebih baik.

Dalam hal ini ada beberapa masalah yang dapat identifikasi, yaitu:

1. Pentingnya melakukan pendataan alumni dengan baik.

2. Kesulitan dalam melakukan pengelolaan data alumni dengan administrasi dalam dokumen cetak, buku, dsb.

3. Kesulitan dalam melakukan pendataan alumni jika pendaftaran harus dilakukan langsung.

4. Perlu adanya analisis kualitas perangkat lunak untuk menjamin kualitas perangkat lunak tersebut.

Berdasarkan uraian di atas tentang pentingnya pengelolaan data yang baik dan efisien maka permasalahan dititikberatkan pada komputerisasi sistem pengelolaan data alumni sekolah. Permasalahan yang diselesaikan dalam penelitian ini dapat dirumuskan sebagai berikut:

1. Bagaimana membuat perangkat lunak sistem manajemen informasi untuk pengelolaan data alumni?

2. Bagaimana tingkat kualitas perangkat 
lunak yang dikembangkan dari sisi functionality, security, usability, efficiency, portability, dan maintainability?

\section{Pengertian Data dan Informasi}

Data dapat didefinisikan sebagai deskripsi dari suatu dan kejadian yang dihadapi (Al-B ahra bin Ladjamudin, 2005). Data dapat berupa catatan-catatan dalam kertas, dokumen, buku, kondisi, situasi, ide, objek, dsb. Data akan menjadi bahan dalam suatu proses pengolahan data, yang kemudian akan diolah menjadi suatu bentuk yang lebih mempunyai arti dan memiliki manfaat. Pengolahan data adalah proses perubahan bentuk data menjadi informasi yang memiliki kegunaan. Semakin banyak data dan kompleksnya aktivitas pengolahan data, maka metode pengelolaan data yang tepat sangat dibutuhkan. Salah satu metode untuk mengolah data adalah dengan menggunakan komputer. Permasalahan yang menggunakan perhitungan matematis atau fungsi-fungsi lainnya, dapat diselesaikan dengan sedikit mungkin kesalahan yang akan terjadi.

Sistem adalah kumpulan dari komponen-komponen yang memiliki unsur keterkaitan antara satu dan lainnya. Sehingga dapat dikatakan bahwa sistem adalah merupakan suatu hal yang saling terkait satu sama lain untuk mencapai sebuah tujuan yang sama (Indrajit, 2000). Informasi, adalah data yang telah diolah menjadi sebuah bentuk yang berarti bagi penerimanya dan bermanfaat dalam mengambil keputusan saat ini atau mendatang (Davis \& Olson, 1974). Kemudian menurut Nugroho (2004), informasi merupakan data yang telah diolah sedemikian rupa sehingga memiliki makna tertentu bagi penggunanya. Berdasar definisi di atas maka dapat dikatakan bahwa sebuah informasi adalah data yang mempunyai makna, artinya ketika sesuatu hal (data) tidak mempunyai makna maka belum dapat dikatakan sebagai sebuah informasi. Menurut Oetomo (2002), Sistem Informasi adalah kumpulan elemen yang saling berhubungan satu sama lain yang membentuk satu kesatuan untuk mengintegrasikan data, memproses dan menyimpan serta mendistribusikan informasi. Secara umum Sistem Informasi merupakan kombinasi dari orang (people), perangkat keras (hardware), perangkat lunak (software), jaringan komunikasi (communications networks), dan sumber data yang dihimpun, ditransformasi, dan mengalami proses pengaliran dalam suatu organisasi (Kristanto, 2003).

\section{Pengembangan dan Rekayasa Aplikasi Web}

Rekayasa Web adalah suatu model rekayasa perangkat lunak (Software Engineering) yang digunakan untuk pengembangan aplikasi-aplikasi web. Sebuah aplikasi web adalah suatu sistem perangkat lunak yang berbasiskan teknologi dan standard dari konsorsium World Wide Web (W3C) yang menyediakan sumber yang bersifat spesifik seperti konten atau layanan melalui sebuah tampilan antar muka (user interface) yang disebut Web Browser (Adri, 2008). Aplikasi web mempunyai beberapa karakteristik yang beberapa diantaranya adalah (Woojong, 2005):

1. Aplikasi web berbeda dengan Software Aplikasi. Kontennya terdiri dari berbagai bentuk dan format data seperti teks, grafis, image, audio, video, yang terintegrasikan oleh pemrosesan proseduran (web programming), metoda yang digunakan dalam menampilkan dan mengatur 
konten tersebut akan berdampak terhadap waktu respon dari sistem (performance).

2. Aplikasi web ditujukan untuk digunakan oleh komunitas pengguna yang besar, beragam, dan sejumlah user yang tidak dikenali (public user) dengan berbagai kebutuhan, harapan, dan kemampuan. Oleh karena itu pada saat mengembangkan aplikasi web, tampilan antar muka dan fiturfitur kemudahan dalam penggunaan (usability features) harus mampu menjawab kebutuhan dari semua user tersebut tanpa harus melalui suatu program latihan. Semua hal ini merupakan gabungan dari HumanWeb Interaction (HWI), user interface, dan information presentation. Semua aplikasi web menuntut aspek "good look and feel", suatu aspek yang memenuhi nilai estetika dan art sehingga pengguna merasa nyaman dalam menggunakan dan mengakses aplikasi web yang dikembangkan.

3. Media pengiriman konten untuk aplikasi web sangat berbeda dengan software tradisional. Aplikasi web membutuhkan kecocokan dengan berbagai jenis perangkat display, format tampilan, dukungan hardware dan software.

4. Aspek security dan privasi lebih dibutuhkan oleh aplikasi berbasis web jika dibandingkan perangkat lunak tradisional.

\section{Kerangka Kerja (Framework) Pengem- bangan Aplikasi Web}

PHP adalah bahasa pemrograman server-side yang didesain spesifik untuk pengembangan aplikasi berbasis web. Banyak kelebihan dari bahasa pemrograman PHP, antaralain pada aspek performa, skalabilitas, portabilitas, open source, dan terutama untuk terkoneksi dan melakukan manipulasi terhadap sebuah basis data (Supaartagorn, 2011). Manajemen basis data dilakukan dengan Structure Query Language (SQL). Beberapa studi menyatakan bahwa bahasa query database tradisional tidak mudah digunakan untuk pengguna teknologi basis data yang tidak berpengalaman, sebagai konsekuensi karena interaksinya berbasis bahasa tekstual, seperti SQL (Avensano, Canfora, De Lucia, \& Stefanucci, 2002).

Kerangka kerja perangkat lunak (software framework) adalah desain dasar yang dapat digunakan dan dikembangkan kembali untuk sebuah sistem atau subsistem aplikasi. Sebuah software framework menyediakan kumpulan kode dasar yang dapat membantu dalam proses pengembangan dan penggabungan komponen yang berbeda pada sebuah perangkat lunak (Paikens \& Arnicans, 2008). Sebuah kerangka kerja pemrograman dapat menyederhanakan proses menyusun kode fungsi program dengan mengurangi kode operasi-operasi yang bersifat repetitive (Upton, 2007). Karena tujuan framework adalah membantu melakukan aktivitas umum, banyak framework menyediakan pustaka (library) untuk akses database, manajemen data sesi, dsb (DocForge, 2010). Kerangka kerja pemrograman web berbasis bahasa pemrograman PHP-Hypertext Preprocessor memudahkan proses pengembangan aplikasi, membantu menyusun fungsifungsi sebuah sistem dengan waktu lebih cepat karena tidak harus menulisnya dari awal. Ini juga dapat meningkatkan kualitas dan stabilitas susunan kode pemrograman (Yicheng, 2011). Framework secara signifikan mengurangi waktu, sumber daya, usaha, yang dibutuhkan untuk mengembangkan dan mengelola aplikasi web. Selain itu, framework adalah arsi- 
tektur terbuka yang berbasis standard umum yang digunakan (Shan \& Hua, 2006).

Dalam desain sistem (design pattern), dikenal dengan baik salah satunya pendekatan Model-View-Controller (Buschmann, 1996), yang dapat membuat mudah dalam proses pengembangan dan mengelola sebuah aplikasi, karena (Leff \& Rayfield, 2001): (1) tampilan (output) aplikasi dapat berubah drastis tanpa merubah struktur data dan business logic, (2) aplikasi dapat dengan mudah dikelola/digunakan dengan antarmuka (interfaces) yang berbeda-beda, misal adalah multi bahasa, atau pengaturan hak akses user yang berbeda-beda.

Pendekatan Model-View-Controller design pattern adalah cara yang mudah untuk mengembangkan arsitektur sistem perangkat lunak interaktif (Krasner \& Pope, 1988). Dikenal juga sebagai Presentation/Abstraction/Control (PAC) design pattern, gagasan utamanya adalah untuk memisahkan antarmuka dan data dibawahnya (Coutaz, 1987). Pola ModelView-Controller terbukti efektif untuk menciptakan dan mengorganisir aplikasi modular (Hofmeister, Nord, \& Soni, 2000).

Salah satu macam kerangka kerja pemrograman web berbasis bahasa pemrograman PHP dan menggunakan pendekatan Model-View-Controller (MVC) adalah CodeIgniter yang dikembangkan oleh EllisLab, Inc. CodeIgniter adalah yang memiliki banyak fitur dengan kebutuhan sistem yang ringan dan dapat mempermudah dalam pengembangan sebuah aplikasi web yang kaya akan content (rich application). Dengan menggunakan perangkat kerangka kerja CodeIgniter framework, dapat mengurangi jumlah baris kode program, sehingga dapat meminimalisasi kesalahan penulisan kode program, mengurangi besarnya ukuran file, dan mempercepat eksekusi program (Upton, 2007). Codeigniter framework memiliki banyak library dengan kelebihan lainnya, terutama untuk menangani keamanan data melalui proses POST data filtering saat eksekusi dan kemampuan untuk melakukan kompresi dokumen (EllisLab Inc., 2011).

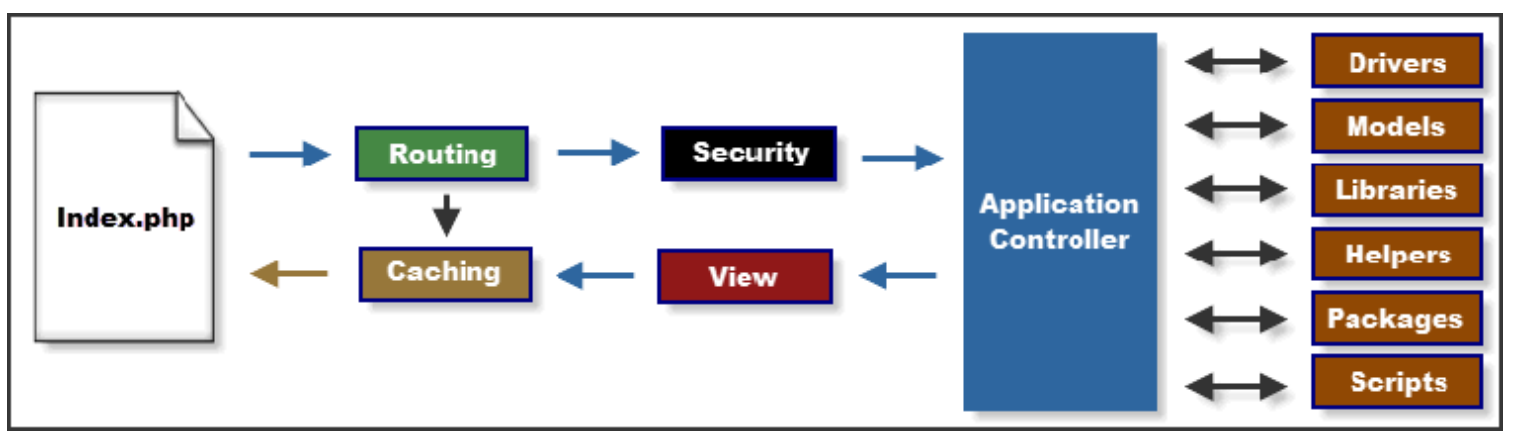

Gambar Arsitektur CodeIgniter Framework

(Sumber: CodeIgniter User Guide) 
Cara kerja framework Codeigniter dimulai dari awal saat client melakukan request ke server, kemudian framework akan melakukan cek terlebih dahulu pada routing database untuk mengetahui controller apa yang akan dieksekusi. Jika pernah dieksekusi dan disimpan dalam cache, framework akan melakukan redirect ke cache tersebut, sehingga dapat mengurangi waktu proses. Data input akan melalui security layer dimana akan dilakukan filtering dan sanitasi data, sehingga input data yang masuk ke dalam sistem sudah bersih dan valid, tidak mengandung kode asing yang dapat membahayakan sistem. Berikutnya, sistem menjalankan controller yang diminta, sekaligus menyediakan library yang dibutuhkan. Terakhir, output data ditampilkan melalui proses View.

\section{PEMBAHASAN}

Penelitian dan pengembangan adalah suatu proses atau langkah-langkah untuk mengembangkan suatu produk baru atau menyempurnakan produk yang telah ada, yang dapat dipertanggungjawabkan (Sukmadinata, 2010). Metode penelitian dan pengembangan (Research and Development) adalah metode penelitian yang digunakan untuk menghasilkan produk tertentu, dan menguji keefektifan produk tersebut (Sugiyono, 2010).

Dengan demikian, pengembangan lebih diarahkan pada upaya menghasilkan produk siap untuk digunakan secara nyata di lapangan, bukan hanya menemukan pengetahuan atau menguji hipotesis atau teori tertentu. Penelitian dan pengembangan yang dilakukan difokuskan pada pembuatan perangkat lunak sistem informasi untuk pengelolaan data alumni pada Sekolah Menengah Atas (SMA).

\section{Tahap Analisis Kebutuhan}

Pada tahap awal ini dilakukan analisis kebutuhan awal mengenai kebutuhan serta problem-problem yang perlu diselesaikan. Dibutuhkan berbagai sumber informasi mengenai kasus dan kebutuhan yang dibutuhkan oleh pengguna, diantaranya pada pihak sekolah, pengelola administrasi sekolah, serta alumni sekolah yang bersangkutan. Kemudian dibuat daftar permintaan atau kebutuhan pengguna (user requirement list) yang perlu disediakan pada aplikasi pengelolaan data alumni sekolah yang dikembangkan dalam penelitian ini.

\section{Tahap Desain}

Berdasarkan dari analisis kebutuhan maka dapat diketahui apa saja yang menjadi kebutuhan dari pengembangan sistem informasi pengelolaan data alumni untuk sekolah, sehingga sistem yang dibuat nantinya sesuai dengan apa yang diharapkan. Tahap desain meliputi:

a) Perancangan Unified Modeling Language (UML)

Perancangan cara kerja program menggunakan UML yang meliputi desain Use Case Diagram dan Class Diagram.

b) Perancangan Diagram Alir (Flowchart)

Diagram (Flowchart) digunakan untuk memperjelas perancangan dan algoritma yang dibuat.

c) Perancangan antar muka pengguna (User Interface)

Rancangan interfaces dari aplikasi web ini yang menggunakan CSS terintegrasi dengan HTML.

d) Perancangan desain basis data. Mendesain tabel-tabel data yang dibutuhkan serta menjelaskan relasi antar tabel. 


\section{Tahap Implementasi}

Implementasi merupakan tahap saat pembuatan aplikasi dimulai setelah dilakukan analisis dan desain. Rancangan program yang telah disiapkan kemudian diimplementasikan dalam bahasa pemrograman, sehingga semua fungsi dapat dijalankan dengan baik oleh pengguna.

\section{Tahap Pengujian}

Pada tahap ini aplikasi yang telah dikembangkan kemudian diberikan berbagai rangkaian pengujian kualitas perangkat lunak yang menggunakan beberapa instrumen penelitian sesuai standard ISO 9126, sehingga dapat dilakukan evaluasi sistem sebelum akhirnya dapat digunakan oleh banyak pengguna.

Untuk mengetahui kualitas perangkat lunak yang dikembangkan dalam penelitian ini, perangkat lunak diuji dan dianalisis memakai standard ISO 9126, terutama pada aspek functionality, security, usability, efficiency, maintainability, dan portability.

\section{a) Pengujian Functionality}

Pengujian ini berfokus pada kesesuaian satu set fungsi untuk dapat melakukan tugas-tugas tertentu. Pengujian ini menggunakan metode checklist yang dilakukan pada 5 responden ahli dengan kriteria responden memiliki pekerjaan sehari-sehari sebagai pengembang aplikasi web.

\section{b) Pengujian Security \\ Pengujian ini berfokus pada jaminan kemampuan dalam mencegah akses yang}

tidak sah, baik secara sengaja maupun tidak disengaja. Pengujian ini dilakukan untuk menemukan berbagai celah keamanan. Pengujian akan dilakukan dengan menggunakan perangkat lunak khusus untuk menguji kualitas sebuah aplikasi web dari sisi security.

\section{c) Pengujian Usability}

Pengujian ini dilakukan dengan menilai seberapa mudah tampilan antarmuka, navigasi, pada perangkat lunak yang dikembangkan untuk digunakan. Pengujian ini menggunakan kuisioner yang dilakukan pada 15 responden dengan kriteria bahwa responden tersebut terbiasa dengan aktifitas internet.

\section{d) Pengujian Efficiency}

Pengujian aspek efisiensi yang dilakukan adalah kualitas performance aplikasi saat diakses pengguna (client side), antaralain adalah kecepatan akses, pemakaian resources, dan kecepatan proses data saat eksekusi. Pengujian ini menggunakan perangkat lunak khusus untuk pengukuran besar dokumen kemudian dilakukan analisis load test.

\section{e) Pengujian Maintainability}

Pengujian aspek maintainability yang dilakukan adalah dengan menguji perangkat lunak pada aspek instrumentation, consistency, dan simplicity.

\section{f) Pengujian Portability}

Pengujian untuk aspek portability ini dilakukan dengan menjalankan sistem pengolah data pada browser berbasis desktop dan pada browser berbasis mobile. 


\section{Instrumen Functionality}

Tabel 4. Instrumen Functionality

\begin{tabular}{|c|c|c|}
\hline No. & Fungsi (kebutuhan) & Pertanyaan \\
\hline 1. & Navigasi & $\begin{array}{l}\text { Apakah menu navigasi utama dapat } \\
\text { difungsikan? }\end{array}$ \\
\hline 2. & Berita / Informasi & $\begin{array}{l}\text { Apakah fungsi untuk mengakses berita sudah } \\
\text { berfungsi dengan benar? }\end{array}$ \\
\hline 3. & Pencarian Data & $\begin{array}{l}\text { Apakah fungsi proses pencarian cepat profil } \\
\text { alumni sudah berfungsi dengan benar? }\end{array}$ \\
\hline 4. & Statistik & $\begin{array}{l}\text { Apakah pada halaman depan informasi statistik } \\
\text { jumlah data alumni sudah berfungsi dengan } \\
\text { benar? }\end{array}$ \\
\hline 5. & Registrasi & $\begin{array}{l}\text { Apakah fungsi registrasi pengguna baru sudah } \\
\text { berfungsi dengan benar? }\end{array}$ \\
\hline 6. & Log in / Otentifikasi & $\begin{array}{l}\text { Apakah fungsi login masuk ke dalam sistem } \\
\text { sudah berfungsi dengan benar? }\end{array}$ \\
\hline 7. & Pengelolaan Data & $\begin{array}{l}\text { Apakah fungsi untuk menyunting data profil } \\
\text { alumni sudah berfungsi dengan benar? }\end{array}$ \\
\hline 8. & Pengelolaan Data & $\begin{array}{l}\text { Apakah fungsi untuk mengunggah foto ke data } \\
\text { profil alumni sudah berfungsi dengan benar? }\end{array}$ \\
\hline 9. & Pengelolaan Data & $\begin{array}{l}\text { Apakah fungsi untuk melihat profil alumni } \\
\text { sudah berfungsi dengan benar? }\end{array}$ \\
\hline 10. & Pengelolaan Data & $\begin{array}{l}\text { Apakah fungsi untuk merubah kata kunci } \\
\text { (password) untuk masuk dalam sistem (login) } \\
\text { sudah berfungsi dengan benar? }\end{array}$ \\
\hline 11. & Pencarian Data & $\begin{array}{l}\text { Apakah fungsi untuk mencari data alumni sudah } \\
\text { berfungsi dengan benar? }\end{array}$ \\
\hline 12. & Berita / Informasi & $\begin{array}{l}\text { Apakah fungsi untuk mengakses informasi } \\
\text { beasiswa sudah berfungsi dengan benar? }\end{array}$ \\
\hline 13. & Statistik & $\begin{array}{l}\text { Apakah fungsi untuk mengakses statistik } \\
\text { lengkap data alumni terdaftar sudah berfungsi } \\
\text { dengan benar? }\end{array}$ \\
\hline 14. & Kontak & $\begin{array}{l}\text { Apakah fungsi untuk menghubungi pengelola } \\
\text { situs sudah berfungsi dengan baik? }\end{array}$ \\
\hline 15. & Cetak Data & $\begin{array}{l}\text { Apakah fungsi untuk mencetak data alumni } \\
\text { sudah berfungsi dengan baik? }\end{array}$ \\
\hline
\end{tabular}

\section{Instrumen Security}

Pengujian ini akan menggunakan perangkat lunak Acunetix Web Vulnerability Scanner versi 8. Pengujian akan dilakukan dengan menggunakan parameter pengujian Default untuk menguji dan menemukan berbagai jenis celah keamanan. Pengujian dilakukan dengan menggunakan login sequence untuk sebuah pengguna biasa. 
Tabel 5. Instrumen Security

\begin{tabular}{|l|l|l|}
\hline No. & Modul dan Manipulasi Parameter & Aktif \\
\hline 1. & Cross Site Scripting $(X S S)$ & Ya \\
\hline 2. & SQL Injection & Ya \\
\hline
\end{tabular}

\section{Instrumen Usability}

Pengujian ini menggunakan

kuisioner Computer System Usability

Questionnaire (CSUQ) yang dikembangkan oleh IBM untuk standar pengukuran usability perangkat lunak (Lewis, 1993).

Tabel 6. Instrumen Usability

\begin{tabular}{|c|c|}
\hline No. & Pertanyaan \\
\hline 1 & $\begin{array}{l}\text { Secara keseluruhan, saya puas dengan kemudahan pemakaian } \\
\text { aplikasi ini. }\end{array}$ \\
\hline 2 & Sangat sederhana penggunaan aplikasi ini. \\
\hline 3 & $\begin{array}{l}\text { Saya dapat dengan sempurna menyelesaikan pekerjaan dengan } \\
\text { aplikasi ini. }\end{array}$ \\
\hline 4 & $\begin{array}{l}\text { Saya dapat menyelesaikan pekerjaan saya dengan cepat } \\
\text { menggunakan aplikasi ini. }\end{array}$ \\
\hline 5 & $\begin{array}{l}\text { Saya dapat menyelesaikan pekerjaan saya secara efisien } \\
\text { menggunakan aplikasi ini. }\end{array}$ \\
\hline 6 & Saya merasa nyaman menggunakan aplikasi ini. \\
\hline 7 & Sangat mudah mempelajari penggunaan aplikasi ini. \\
\hline 8 & $\begin{array}{l}\text { Saya yakin saya bisa menjadi produktif dengan cepat berkat } \\
\text { aplikasi ini. }\end{array}$ \\
\hline 9 & $\begin{array}{l}\text { Pesan kesalahan yang diberikan aplikasi ini menjelaskan dengan } \\
\text { gambling cara mengatasinya. }\end{array}$ \\
\hline 10 & $\begin{array}{l}\text { Kapanpun saya membuat kesalahan, saya bisa memperbaikinya } \\
\text { dengan cepat dan mudah. }\end{array}$ \\
\hline 11 & Informasi yang disediakan aplikasi ini cukup jelas. \\
\hline 12 & Sangat mudah mencari informasi di aplikasi ini. \\
\hline 13 & Informasi yang disediakan aplikasi sangat mudah dipahami. \\
\hline 14 & $\begin{array}{l}\text { Informasi yang disediakan efektif membantu saya menyelesaikan } \\
\text { tugas dan skenario. }\end{array}$ \\
\hline 15 & Pengorganisasian informasi yang ditampilkan aplikasi jelas. \\
\hline 16 & Antarmuka aplikasi menyenangkan. \\
\hline 17 & Saya menyukai menggunakan antarmuka aplikasi ini. \\
\hline 18 & Aplikasi ini memiliki fungsi dan kapabilitas sesuai harapan saya. \\
\hline 19 & Secara keseluruhan, saya puas dengan aplikasi ini. \\
\hline
\end{tabular}

\section{Instrumen Efficiency}

Pengujian ini menggunakan alat ukur YSlow yang dikembangkan oleh Yahoo Developer Network untuk mengukur performa efisiensi sebuah halaman website. Performa yang akan diukur adalah besarnya bytes data dokumen, jumlah HTTP request, minifikasi, kompresi GZIP, dan score / grade akhir (Yahoo Developer Network, 2011). 
Tabel 7. Instrumen Efficiency

\begin{tabular}{|l|l|l|}
\hline No. & Parameter Dasar YSlow & Aktif \\
\hline 1 & Make fewer HTTP requests & Ya \\
\hline 2 & Compress components with GZIP & Ya \\
\hline 3 & Minify JavaScript and CSS & Ya \\
\hline 4 & Reduce DNS lookups & Ya \\
\hline 5 & Reduce cookie size & Ya \\
\hline 6 & Reduce the number of DOM elements & Ya \\
\hline 7 & Configure entity tags (ETags) & Ya \\
\hline 8 & Use cookie-free domains & Ya \\
\hline 9 & Make JavaScript and CSS external & Ya \\
\hline
\end{tabular}

\section{Instrumen Maintainability}

Pengujian untuk aspek maintainability ini menggunakan ukuran-ukuran (metrics). Kemudian pengujian dilakukan peneliti dengan diuji secara operasional (Land, 2002). Instrumen pengujian dapat dilihat pada tabel dibawah ini.

Tabel 8. Instrumen Maintainability

\begin{tabular}{|l|l|l|l|}
\hline Aspek & Aspek yang dinilai & Hasil yang akan diperoleh \\
\hline Instrumentation & $\begin{array}{l}\text { Terdapat peringatan } \\
\text { pada sistem } \\
\text { pengolah data untuk } \\
\text { mengidentifikasi } \\
\text { kesalahan }\end{array}$ & $\begin{array}{l}\text { Ketika ada kesalahan yang dilakukan } \\
\text { oleh user, maka sistem akan } \\
\text { mengeluarkan peringatan untuk } \\
\text { mengidentifikasi kesalahan. }\end{array}$ \\
\hline Consistency & $\begin{array}{l}\text { Penggunaan satu } \\
\text { bentuk rancangan } \\
\text { pada seluruh } \\
\text { rancangan sistem }\end{array}$ & $\begin{array}{l}\text { Bentuk rancangan sistem pengolah data } \\
\text { mempunyai satu bentuk yang sama. Hal } \\
\text { ini dapat dilihat pada bagian } \\
\text { implementasi sistem. }\end{array}$ \\
\hline Simplicity & $\begin{array}{l}\text { Kemudahan dalam } \\
\text { pengelolaan, } \\
\text { perbaikan, } \\
\text { pengembangan dan } \\
\text { sistem }\end{array}$ & $\begin{array}{l}\text { Mudah untuk dikelola, diperbaiki, dan } \\
\text { dikembangkan. Hal ini dapat dilihat pada } \\
\text { tahapan-tahapan proses penulisan kode } \\
\text { program. }\end{array}$ \\
\hline
\end{tabular}

\section{Instrumen Portability}

Pengujian untuk aspek portability ini dilakukan dengan menjalankan sistem pada browser berbasis desktop dan pada browser berbasis mobile (World Wide Web Consortium, 2012). 
Tabel 9. Instrumen Portability

\begin{tabular}{|l|l|}
\hline $\begin{array}{l}\text { Aspek yang } \\
\text { dinilai }\end{array}$ & Hasil yang akan diperoleh \\
\hline $\begin{array}{l}\text { Sistem dapat } \\
\text { berjalan pada } \\
\text { browser berbasis } \\
\text { desktop }\end{array}$ & $\begin{array}{l}\text { Sistem kompatibel dengan beberapa browser ternama. Hal ini } \\
\text { terbukti dari hasil pengujian bahwa sistem dapat di akses di } \\
\text { beberapa browser seperti Mozilla Firefox, Internet Explorer, } \\
\text { Opera, dan Google Chrome tanpa terdapat pesan error. }\end{array}$ \\
\hline $\begin{array}{l}\text { Sistem dapat } \\
\text { berjalan pada } \\
\text { browser berbasis } \\
\text { mobile }\end{array}$ & $\begin{array}{l}\text { Sistem dapat diakses melalui browser berbasis mobile yaitu } \\
\text { Opera Mini tanpa terdapat pesan error. }\end{array}$ \\
\hline
\end{tabular}

\section{Perancangan Diagram Alir (Flow- chart)}

a) Flowchart proses registrasi

Flowchart yang digunakan untuk menjelaskan proses registrasi berjalan.

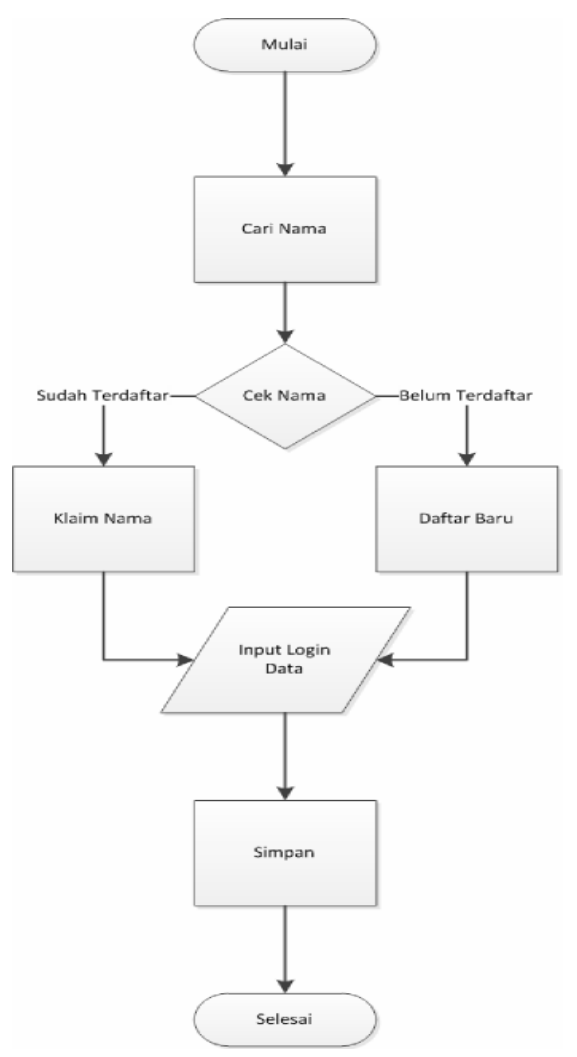

Gambar 16. Flowchart proses registrasi b) Flowchart proses Log in Flowchart yang digunakan untuk menjelaskan proses Log in berjalan.

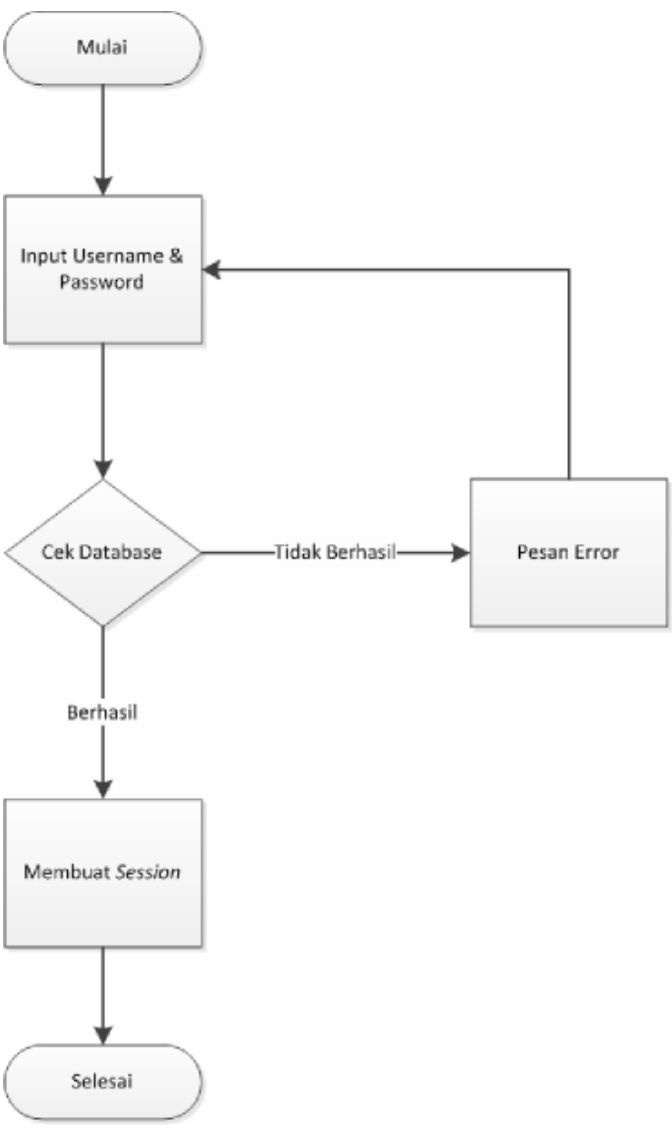

Gambar 17. Flowchart proses Log in 
c) Flowchart proses sunting data Flowchart yang digunakan untuk menjelaskan proses sunting data berjalan.

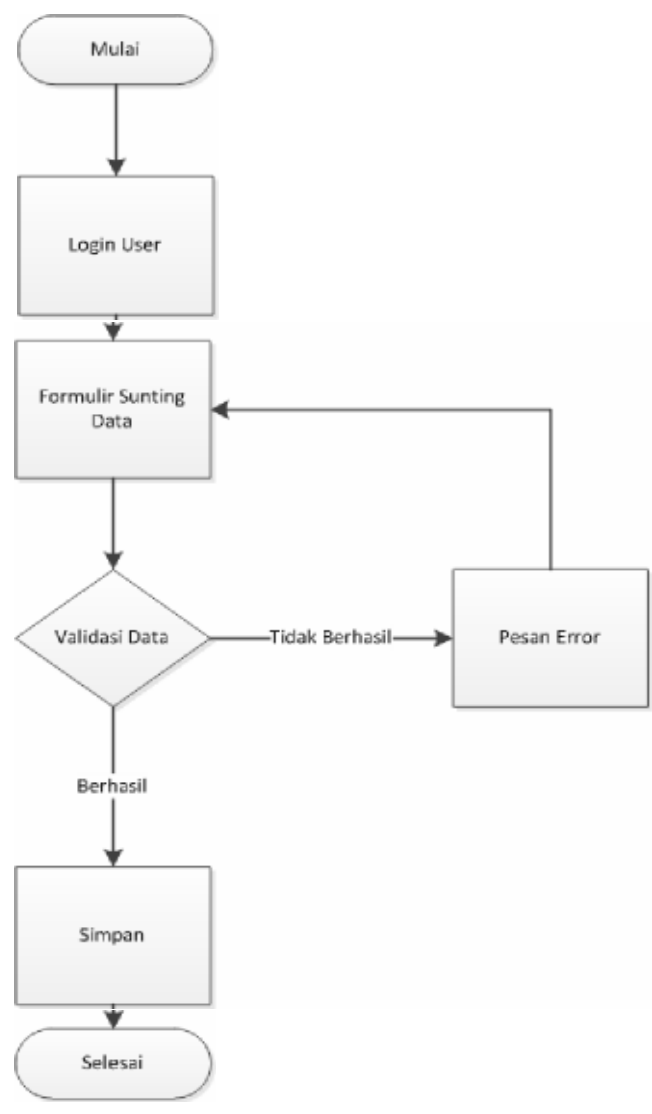

Gambar 18. Flowchart proses sunting data d) Flowchart proses pencarian data Flowchart yang digunakan untuk menjelaskan proses pencarian data berjalan.

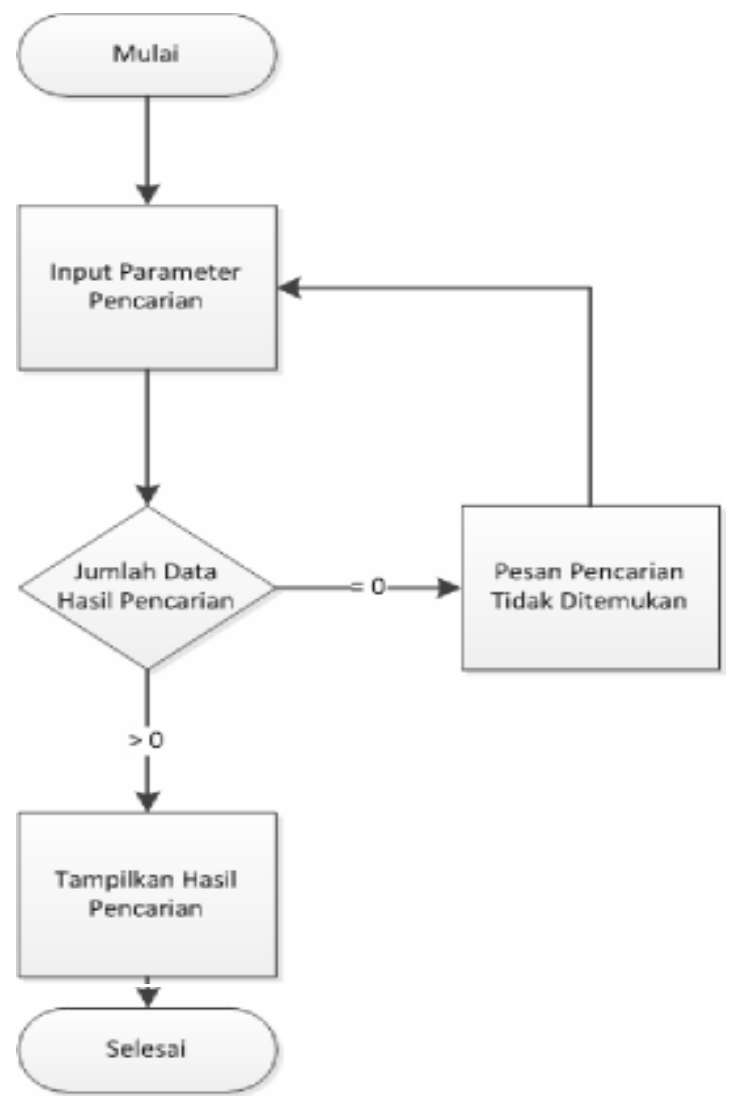

Gambar 19. Flowchart proses pencarian data 
e) Flowchart proses statistik

Flowchart yang digunakan untuk menjelaskan proses statistik berjalan.

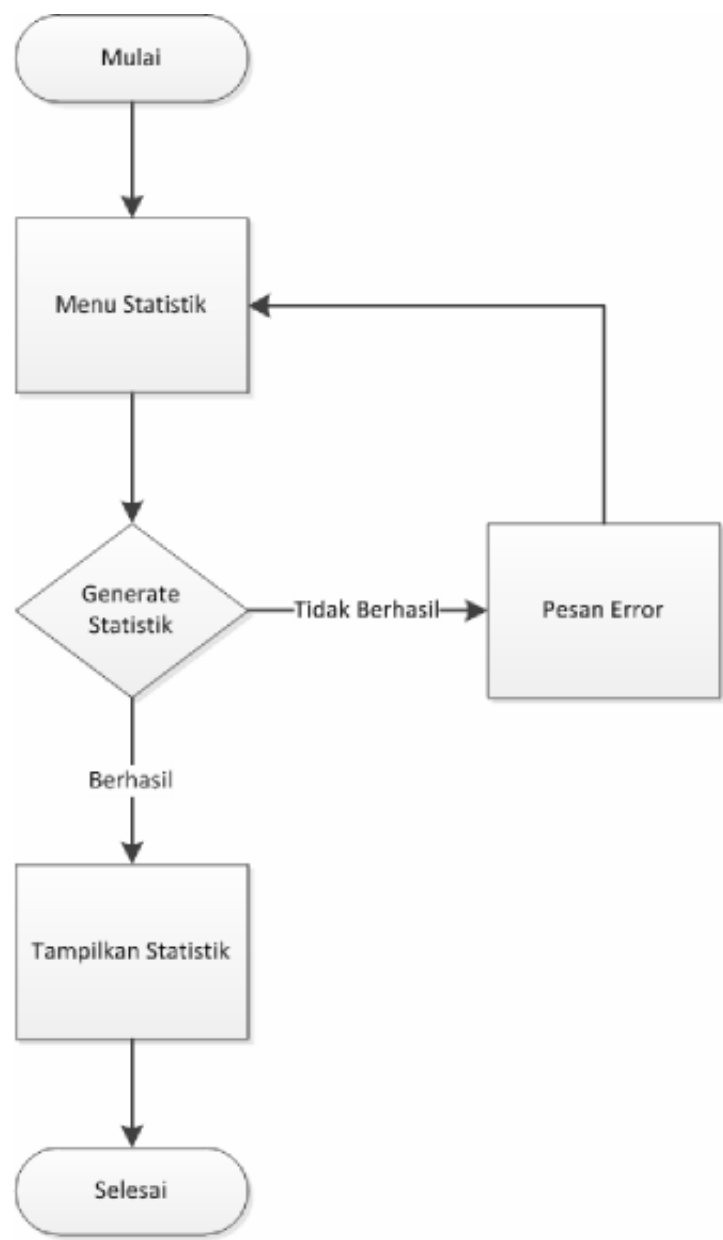

Gambar 20. Flowchart proses statistik f) Flowchart proses cetak data Flowchart yang digunakan untuk menjelaskan proses cetak data berjalan.

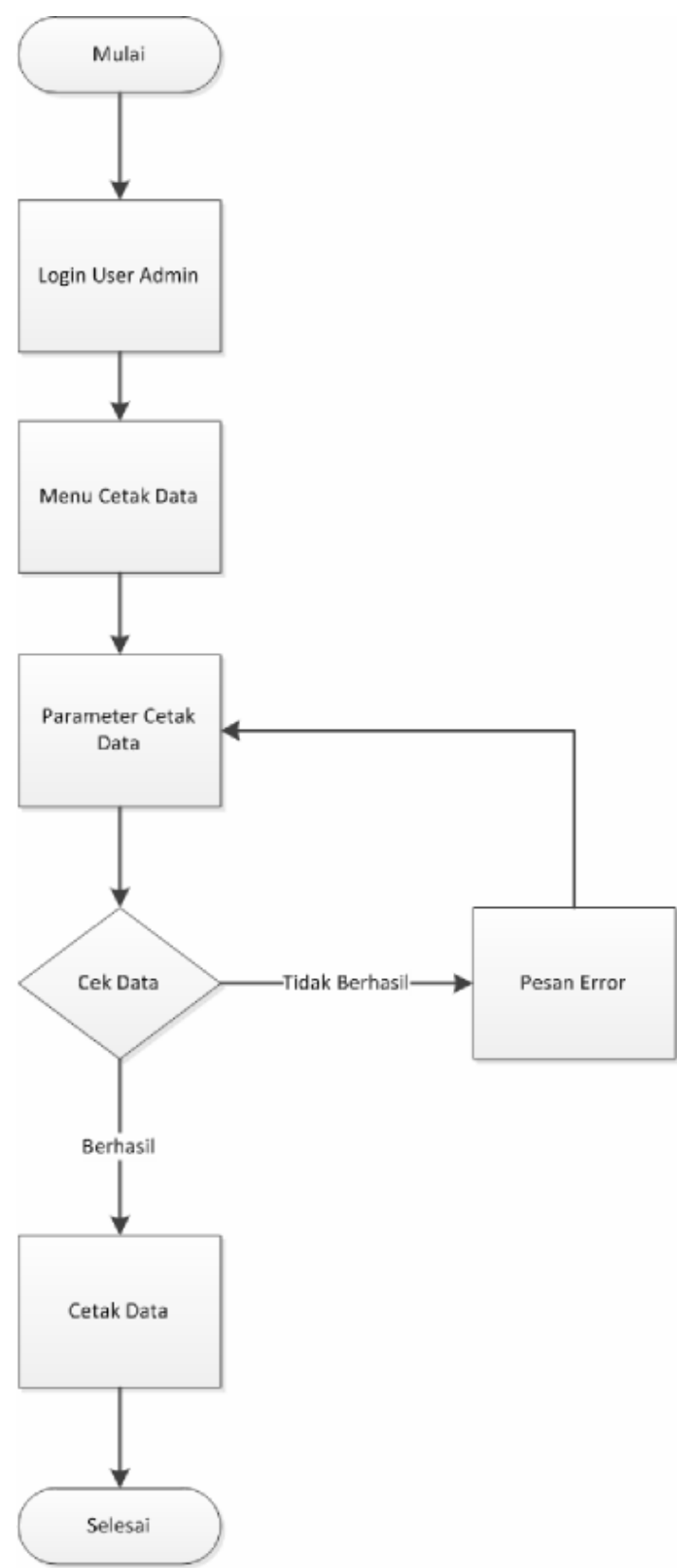

Gambar 21. Flowchart proses cetak data 


\section{Perancangan User Interface (Antar Muka Pengguna).}

a) Halaman Depan

Pada rancangan halaman depan memuat judul aplikasi, kolom navigasi, kotak login, kotak berita, serta menu pencarian cepat

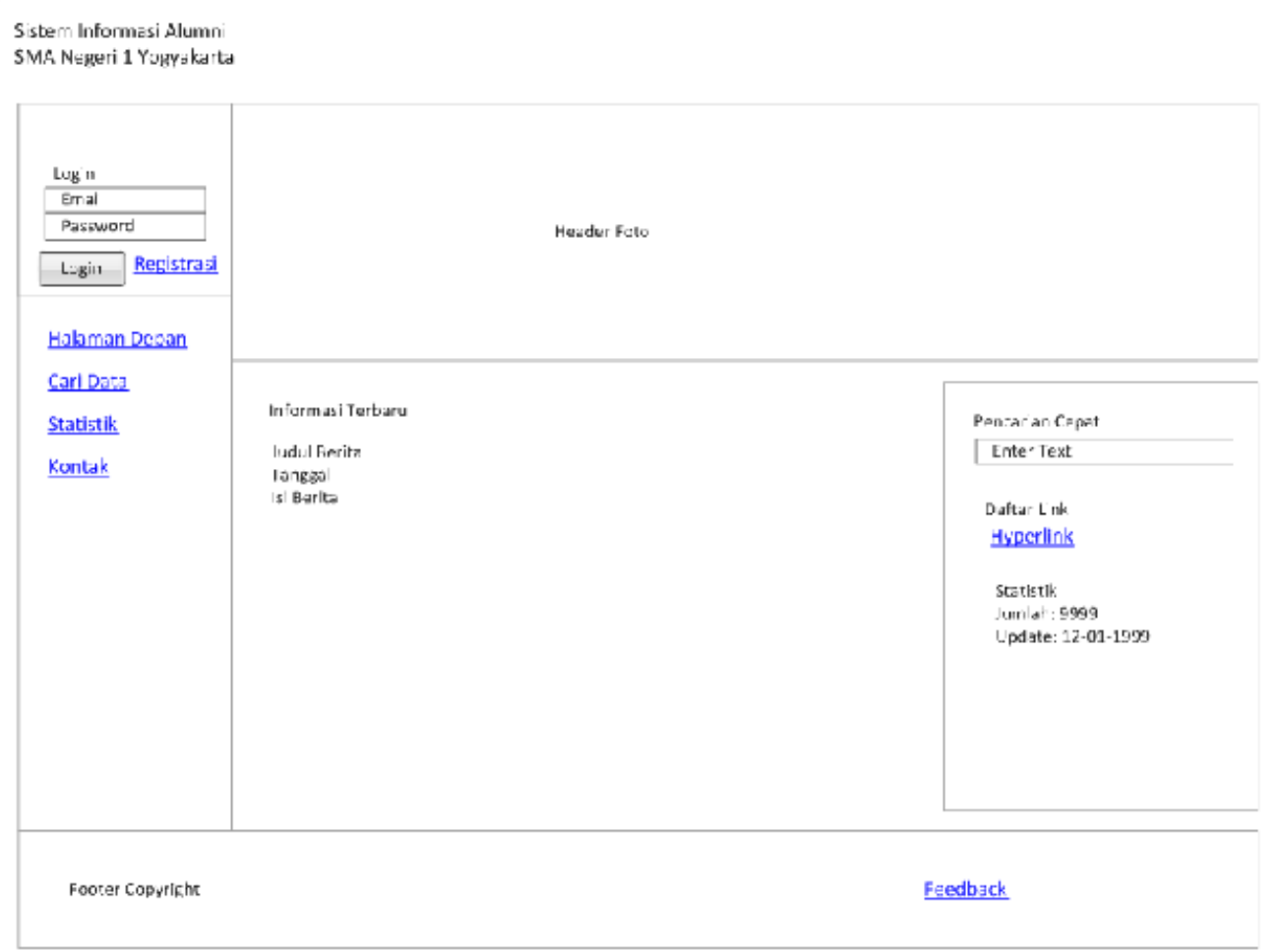

Gambar Rancangan Halaman Depan

b) Halaman Registrasi Langkah ke-1

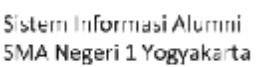

Gambar Rancangan Halaman Registrasi Langkah ke-1 
c) Halaman Registrasi Langkah ke-2

Sistrm Informasi Alumni

5MA Negeri 1 Yogvakarta

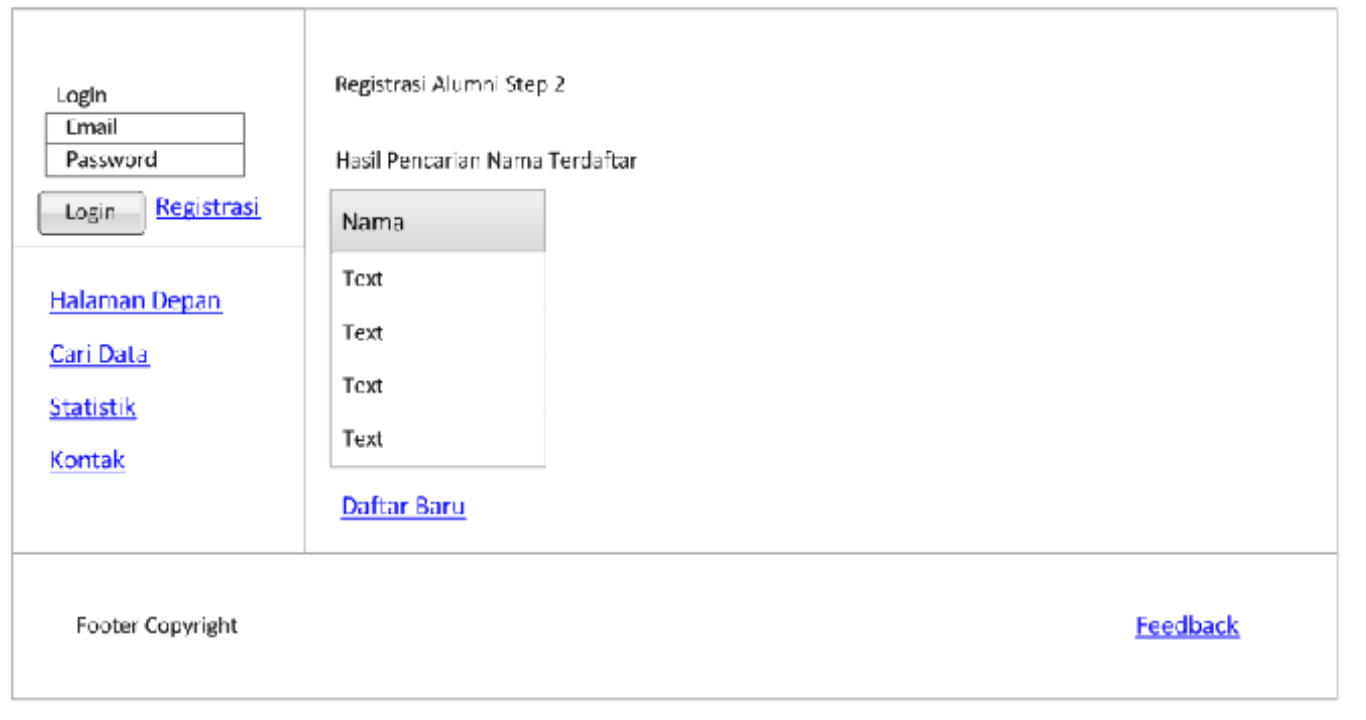

Gambar Rancangan Halaman Registrasi Langkah ke-2

d) Halaman Registrasi Langkah ke-3

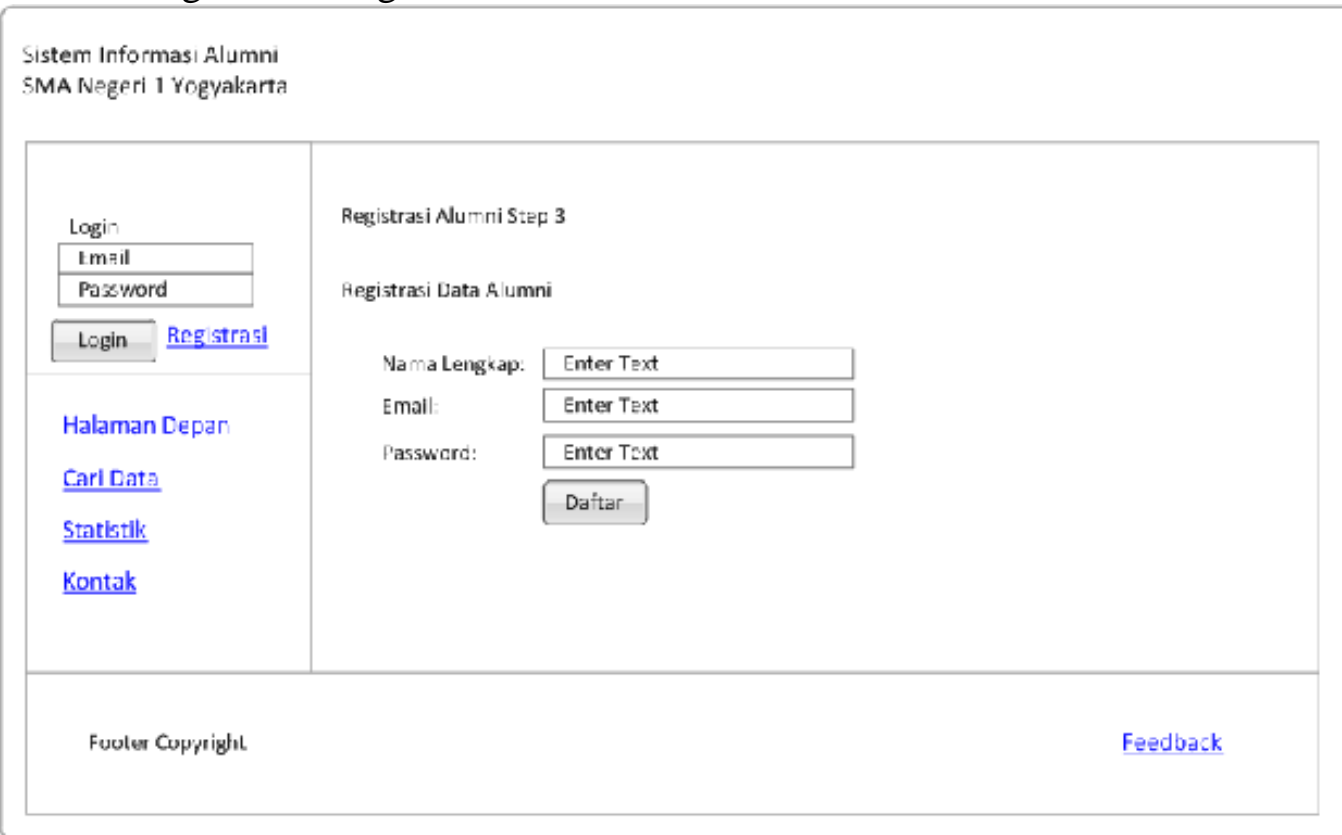

Gambar Rancangan Halaman Registrasi Langkah ke-3 
e) Halaman Registrasi Langkah ke-4

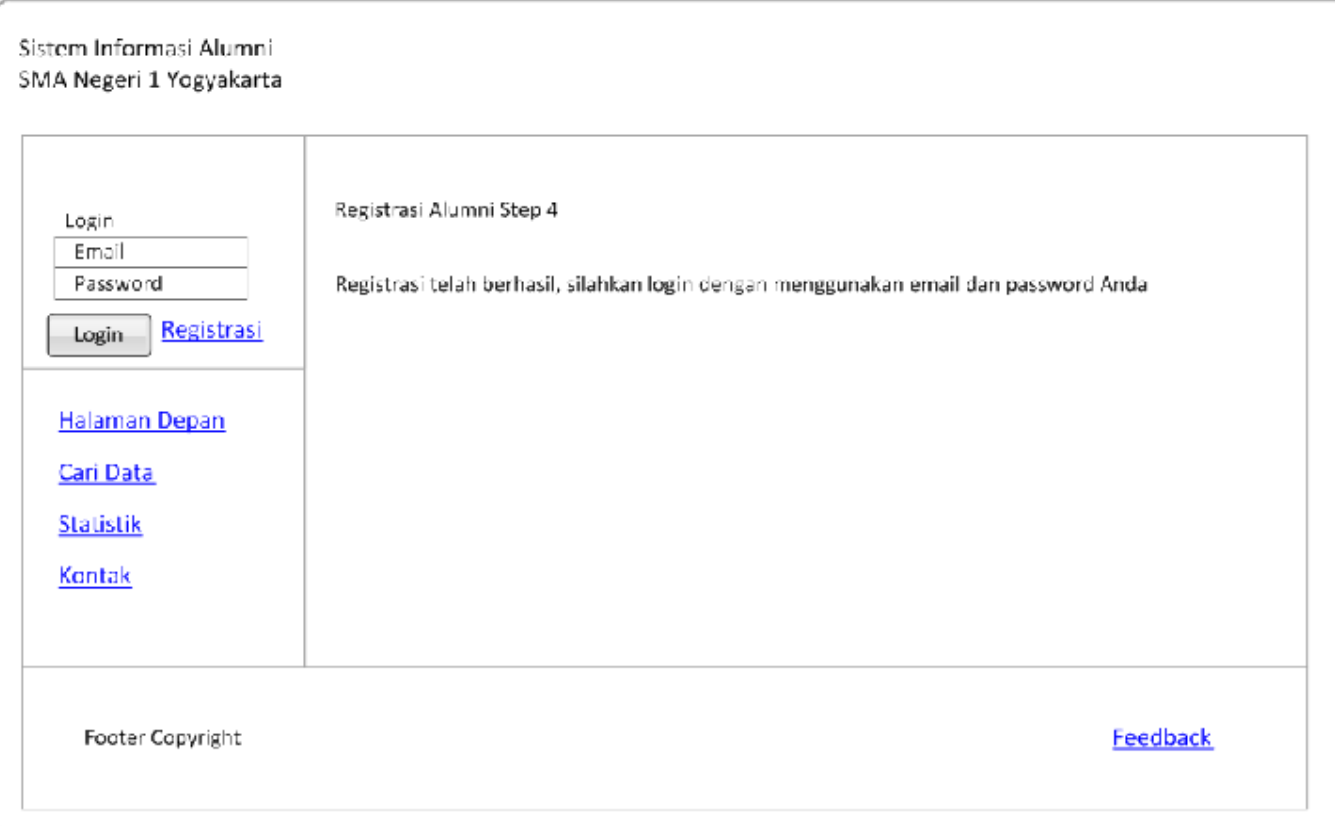

Gambar Rancangan Halaman Registrasi Langkah ke-4

f) Halaman Log in pengguna

$$
\begin{aligned}
& \text { Sis:em Informasi Alumni } \\
& \text { SMA Negeri } 1 \text { Yogya kar:a }
\end{aligned}
$$

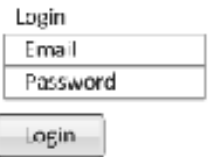

Gambar Rancangan Halaman Log in pengguna 
g) Halaman Sunting Data

\begin{tabular}{|c|c|c|c|}
\hline \multicolumn{4}{|l|}{$\begin{array}{l}\text { Sistem Informasi Alumni } \\
\text { SMA Neger } 1 \text { rogyakatta }\end{array}$} \\
\hline Inforinasi Fengguna & \multicolumn{2}{|c|}{ Menkedit Data A L Lmni } & \\
\hline \multirow{3}{*}{$\begin{array}{l}\text { Nama User } \\
\underline{\text { Logout }}\end{array}$} & \multirow{6}{*}{$\begin{array}{l}\text { Nama Lengkap: } \\
\text { Email: } \\
\text { Passyord: } \\
\text { TL: } \\
\text { Alamat: } \\
\text { Pe'ididikinll: }\end{array}$} & Enter Tex: & \\
\hline & & Enter Text & \\
\hline & & Enter Text & \\
\hline \multirow{2}{*}{ Halaman Depan } & & Enter Text & \\
\hline & & Enter Text & \\
\hline$\underline{\text { Cari Dala }}$ & & Enter Text: & \\
\hline \multicolumn{4}{|l|}{ Statistik } \\
\hline Kontak & & Simpan & \\
\hline Footer Copyrisht: & & & Feedback \\
\hline
\end{tabular}

Gambar Rancangan Halaman Sunting Data

h) Halaman Tampilan Profil

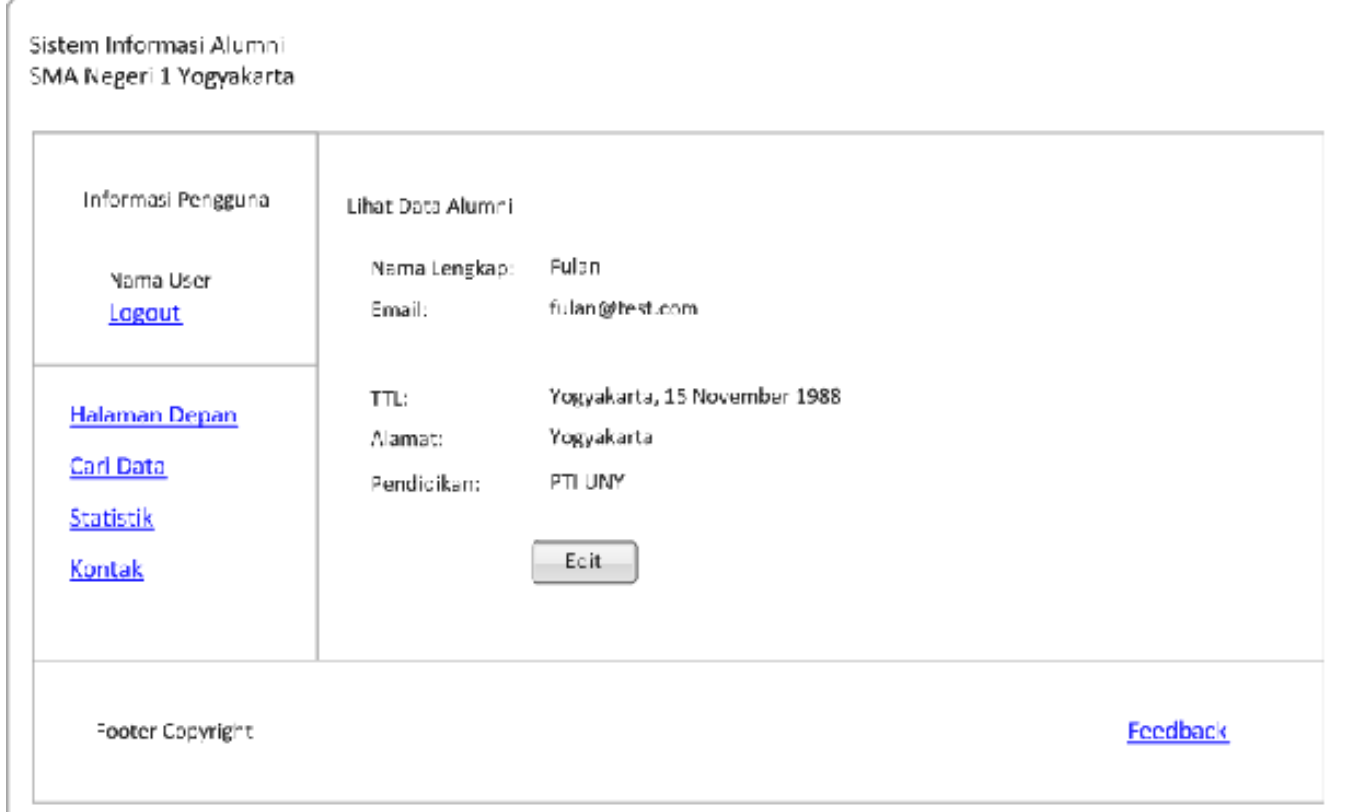

Gambar Rancangan Halaman Tampilan Profil 
i) Halaman Pencarian Data Alumni

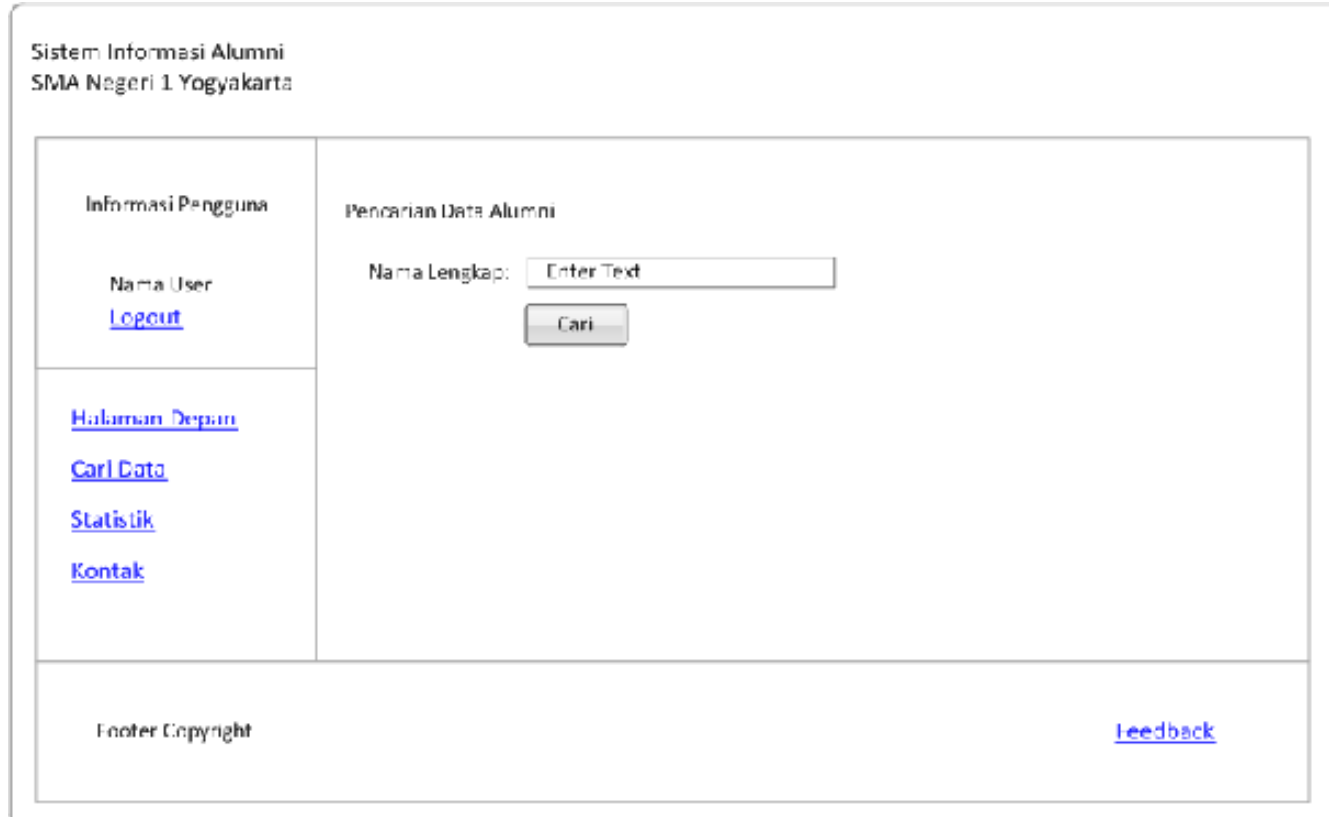

Gambar Rancangan Halaman Pencarian Data Alumni

j) Halaman Hasil Pencarian Data

Sistem Informasi Alumni

SMA Negeri 1 Yogvakarta

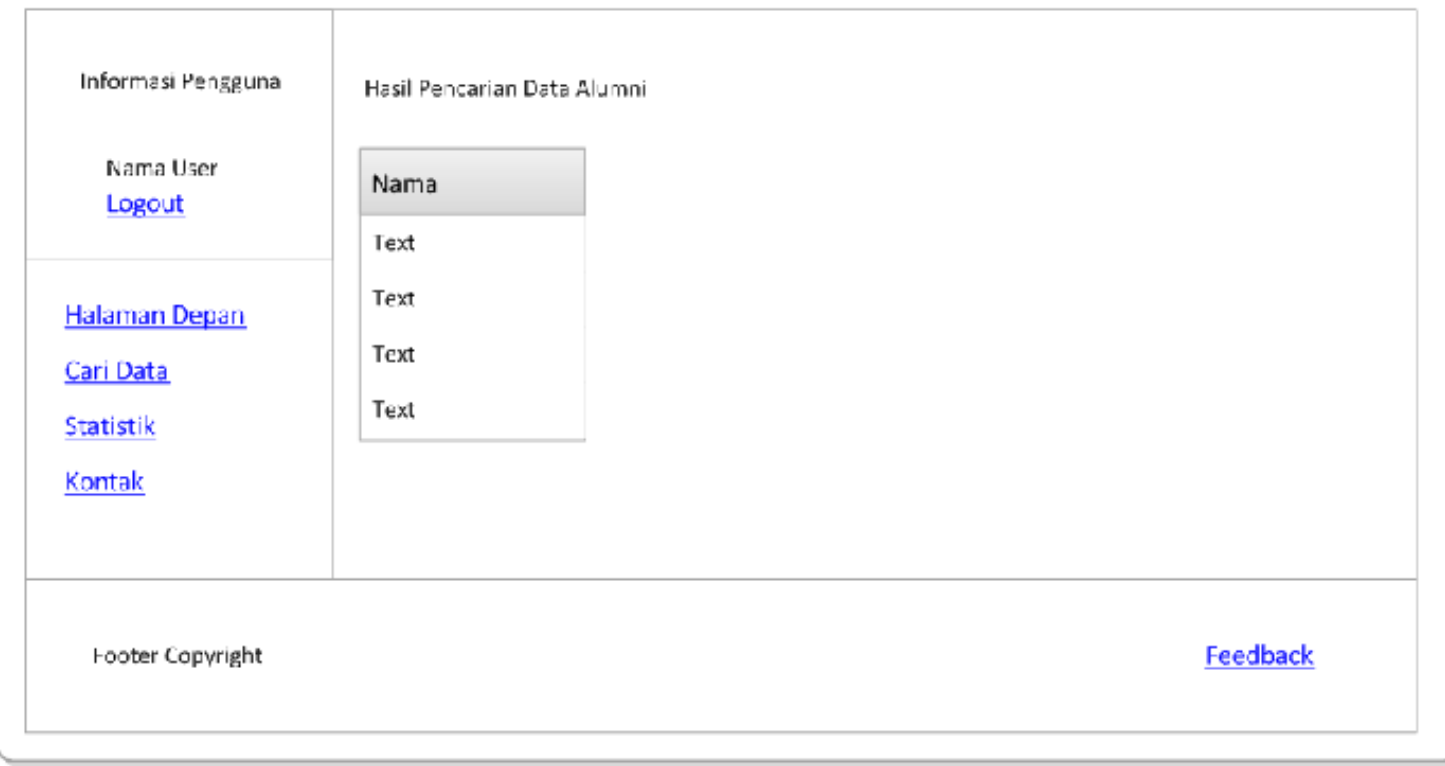

Gambar Rancangan Halaman Hasil Pencarian Data 
k) Halaman Statistik

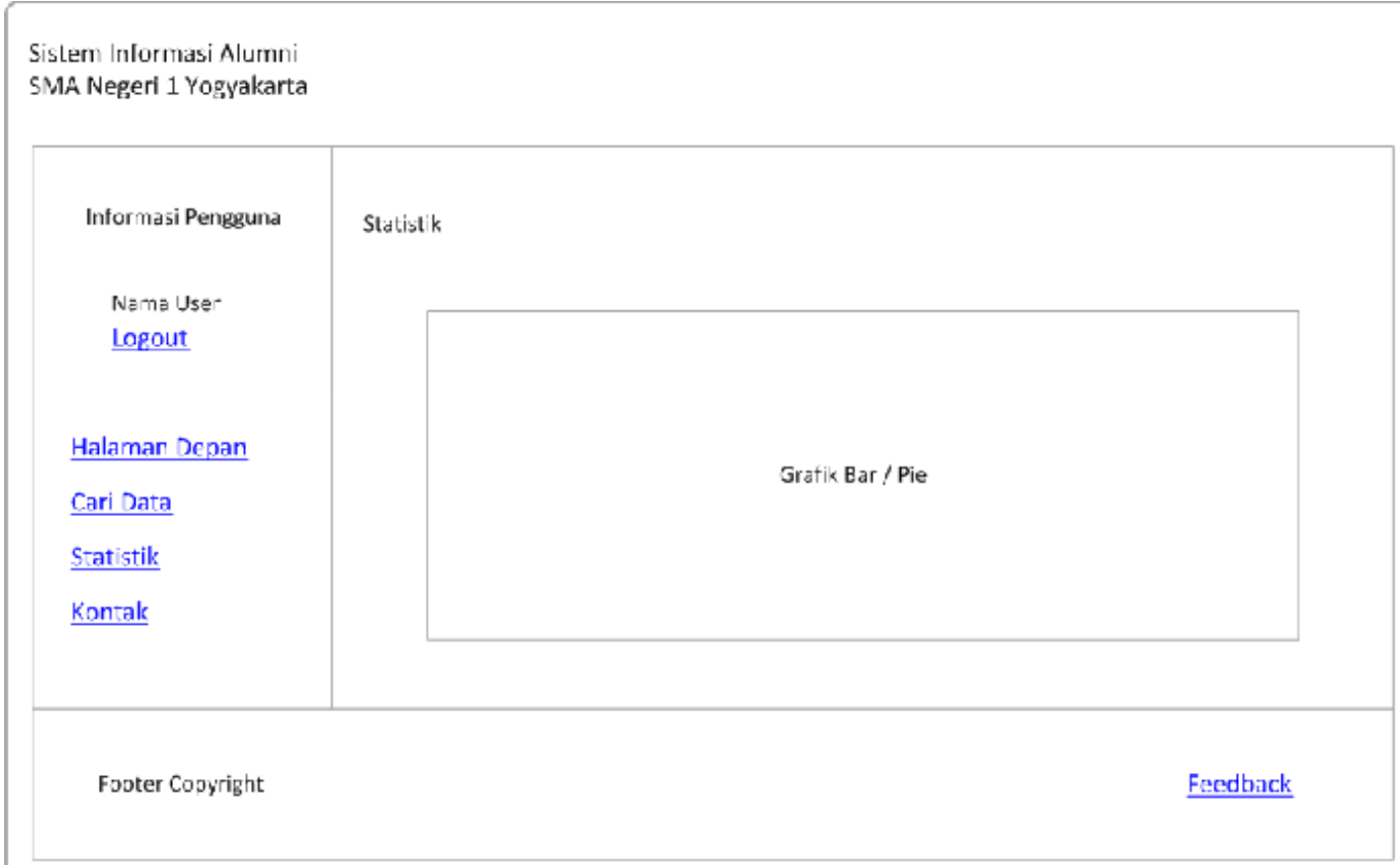

Gambar Rancangan Halaman Statistik

1) Halaman Cetak Data Alumni

Sistem Informasi Alumn।

SMA. Negeri 1 Yogyakarta

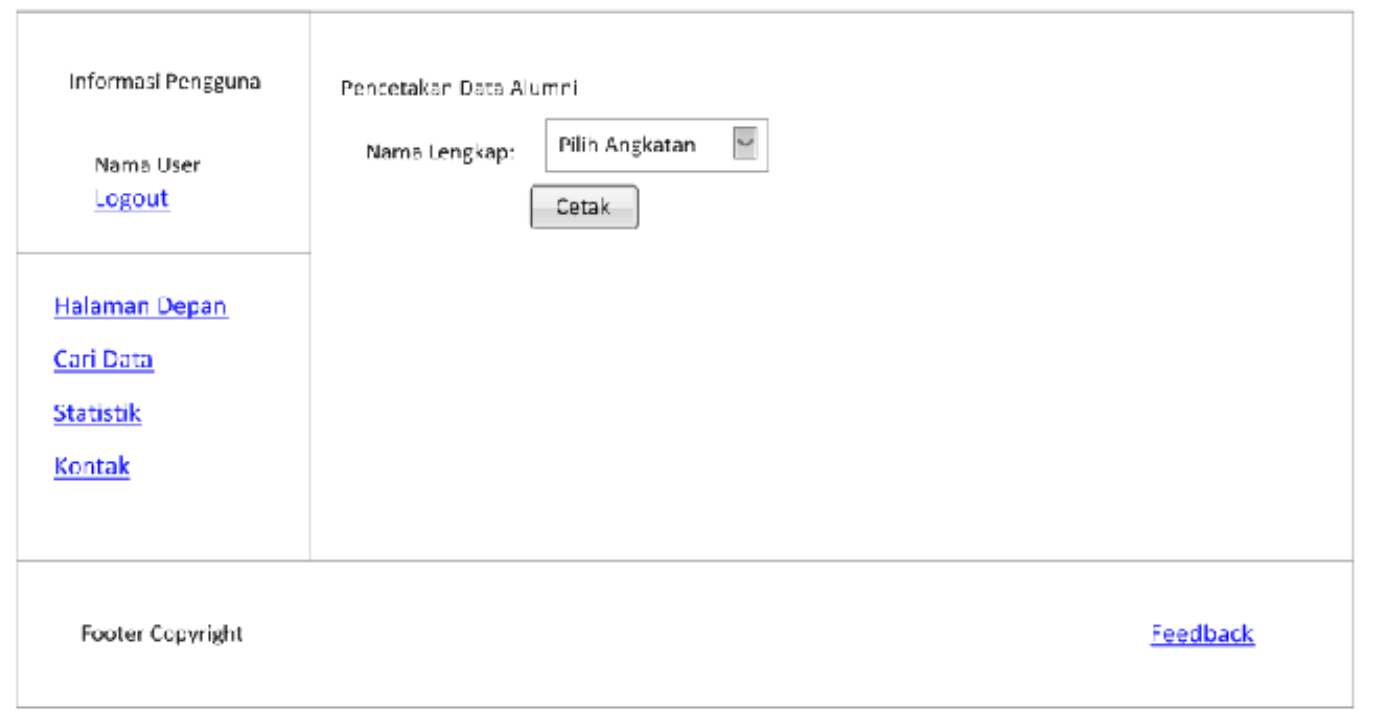

Gambar Rancangan Halaman Rancangan Cetak Data 
Perancangan Desain Basis Data

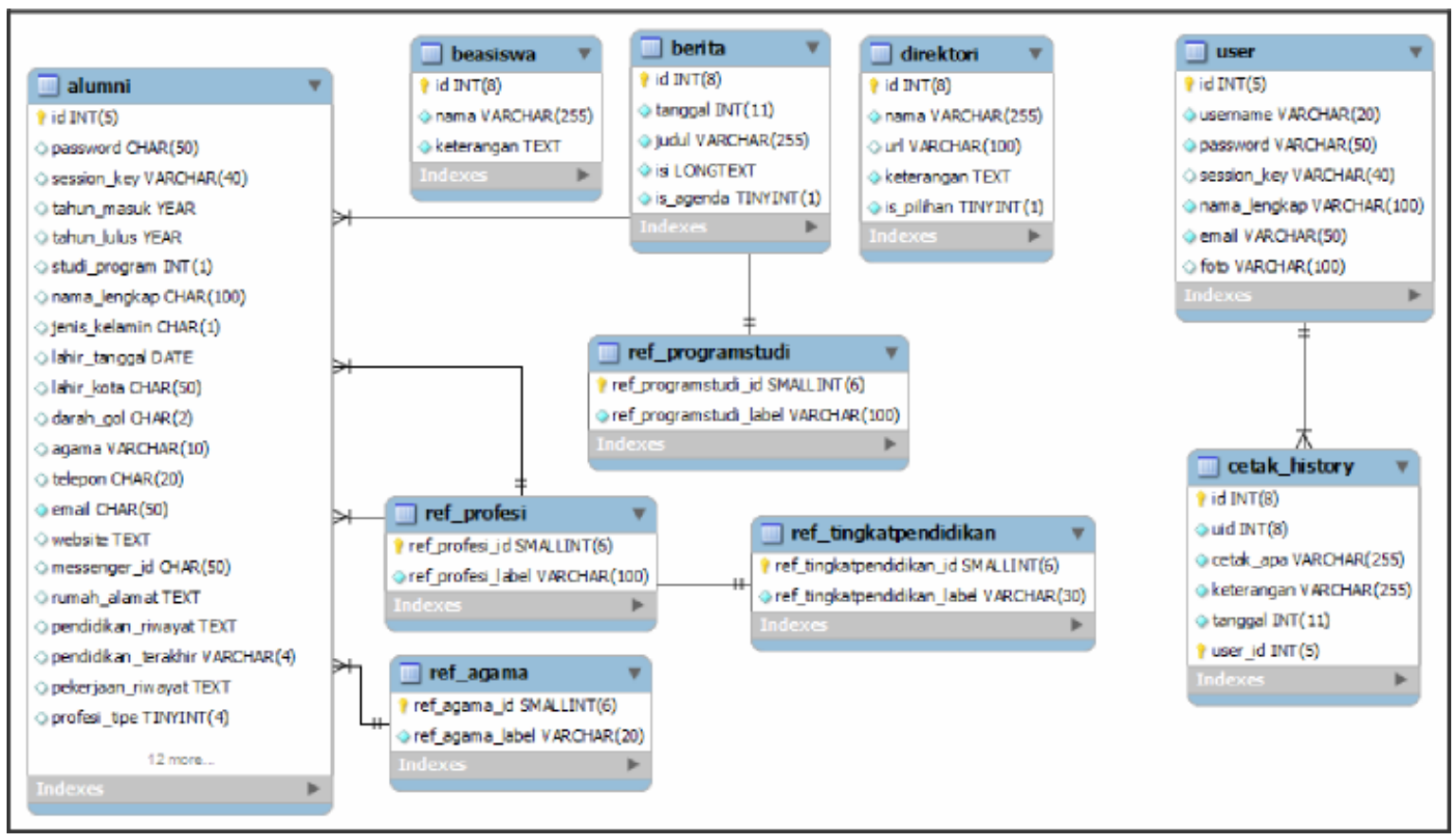

Gambar Rancangan Desain Basis Data

\section{KESIMPULAN}

Berdasarkan hasil pembahasan yang telah dilakukan, dapat disimpulkan bahwa:

1. Dengan menggunakan framework CodeIgniter PHP dapat dibuat sebuah perangkat lunak aplikasi web sistem informasi untuk membantu pengelolaan data. Dalam penelitian ini, perangkat lunak dikembangkan untuk membantu mengelola data alumni sekolah.

2. Dapat diketahui kualitas perangkat lunak berbasis aplikasi web yang dikembangkan terhadap standard ISO 9126, yaitu:

a. Kualitas perangkat lunak yang dikembangkan dari sisi functionality adalah sudah cukup baik, setelah dilakukan pengujian, didapatkan $94,6 \%$ fungsi telah berjalan dengan benar sesuai kebutuhan. b. Dengan menggunakan security layer pada CodeIgniter PHP framework dapat dilakukan data filtering untuk mencegah eksploitasi celah keamanan yang antara lain berupa Cross-site Scripting (XSS) dan SQL Injection. Hal ini bisa dilihat dari hasil pengujian yang hanya menghasilkan peringatan jenis rendah (Low Level). Jadi kualitas perangkat lunak yang dikembangkan dari sisi security sudah cukup bagus.

c. Kualitas perangkat lunak yang dikembangkan dari sisi usability sudah cukup baik, dimana setelah dilakukan pengujian, nilai usability yang didapatkan menyatakan $79 \%$ pengguna dapat dengan mudah menggunakan sistem. Dari skor persentase yang didapat maka 
kualitas dari sisi usability perangkat lunak telah sesuai dengan yang diharapkan pada atribut usability.

d. Framework CodeIgniter PHP dapat melakukan kombinasi dokumen, minifikasi data, dan melakukan kompresi GZIP sebelum data dikirim dari server ke client. Hal ini dapat mengurangi jumlah HTTP Request dan mengurangi besar data dokumen secara signifikan (rata-rata dibawah 50 Kilobytes). Dari pengujian yang dilakukan, didapatkan $70 \%$ halaman web telah memiliki tipe A grade dengan skor di atas 90 dan 30\% halaman web telah memiliki tipe $B$ grade dengan skor diantara 80-89. Dengan menggunakan data faktor kemauan pengguna dalam menunggu load dari sebuah website, didapatkan sebanyak minimal $84 \%$ pengguna tidak akan pergi meninggalkan halaman web tersebut. Dengan demikian kualitas perangkat lunak yang dikembangkan dari sisi efficiency sudah bagus.

e. Framework CodeIgniter PHP yang digunakan memiliki kemampuan untuk melakukan validasi data input, sehingga setiap pengguna memberi masukan data, sistem akan memberi peringatan jika data yang dimasukkan tidak sesuai. Dengan adanya peringatan ini, dapat membantu pengguna untuk memperbaikinya kembali. Halaman-halaman web yang dikembangkan juga terlihat konsisten secara bentuk, warna, tata letak, dsb. Terakhir, framework CodeIgniter PHP dengan pendekatan ModelViewController membuat proses penulisan kode program saat pengembangan aplikasi berbasis web menjadi lebih mudah. Jadi kualitas perangkat lunak yang dikembangkan dari dari sisi maintainability sudah baik

f. Kualitas perangkat lunak yang dikembangkan dari sisi portability sudah baik, dapat dilihat dari keseluruhan halaman aplikasi web dapat diakses tanpa error dengan menggunakan berbagai web browser baik desktop maupun mobile.

\section{REFERENSI}

Aaby, A. (2004). Quality Characteristics. Retrieved Januari 5, 2012, from Software Acquisition: Software from the Customer's Perspective: http://cs.wallawalla.edu/ aabyan/ Colloquia/Acquisition/qualities.h tml (diakses pada tanggal 20 Februari 2016)

Acunetix. (2011). Audit Your Website Security With Acunetix Web Vulnerability Scanner. Retrieved Januari 5, 2012, from http://www.acunetix.com/vulnera bility-scanner/ (diakses pada tanggal 20 Februari 2016)

Adri, M. (2008). Konsep Dasar Web Engineering. Retrieved Januari 5, 2012, from http://muhammadadri.files.wordp ress.com/2008/04/01-materi$\underline{1 . p d f}$ 
Al-Bahra bin Ladjamudin. (2005). Analisis dan Desain Sistem Informasi. Yogyakarta: Graha Ilmu.

Anley, C. (2002). Advanced SQL Injection In SQL Server Applications. An NGSSoftware Insight Security Research (NISR) Publication.

Avensano, L., Canfora, G., De Lucia, A., \& Stefanucci, S. (2002). Understanding SQL Through Iconic Interfaces. Computer Software and Applications Conference (COMPSAC), (pp. 703-708).

Buschmann, F. (1996). Pattern-Oriented Software Architecture: A System of Patterns. 123-168.

Centre for Software Engineering. (1991). ISO/IEC 9126 : Information Technology Software Product Evaluation Quality Characteristics and Guidelines for Their Use. Retrieved Januari 5, 2012, from ISO 9126: The Standard of Reference:

http://www.cse.dcu.ie/essiscope/s m2/9126ref.html

Coutaz, J. (1987). PAC, An ObjectOriented Model for Dialog Design. Proceedings of HumanComputer Interaction (INTERACT) (pp. 43 1-436). Elsevier Science Publishers.

Davis, G. B., \& Olson, H. M. (1974). Management Information System: Conceptual Foundation, Structure, and Development.
Aucklland:

McGraw-Hill International Book Company.

Departemen Pendidikan Nasional. (2002). Manajemen Peningkatan Mutu Berbasis Sekolah, Konsep Dasar. Jakarta: Ditj end Pendidikan Dasar dan Menengah.

EllisLab Inc. (2011). CodeIgniter User Guide Version 2.1.0. Retrieved Januari 5, 2012, from http://codeigniter.com/user_guid e/index.html

Hofmeister, C., Nord, R. L., \& Soni, D. (2000). Applied Software Architecture. Addion-Wesley.

Huang, Y. W., Huang, S. K., Lin, T. P., \& Tsai, C. H. (2003). Web Application Security Assessment by Fault Injection and Behavior Monitoring. Proceedings of the 12th International Conference on World Wide Web (pp. 148-159). New York, NY, USA: ACM.

Indrajit, R. E. (2000). Manajemen Sistem Informasi dan Teknologi Informasi : Pengantar Konsep. Jakarta: Gramedia.

Kan, Z. (2010). Web Interoperability, An Obstruction of FLOSS Development. Tsinghua University.

Krasner, G. E., \& Pope, S. T. (1988). A Cookbook for Using the ModelViewController User-Interface Paradigm in Smalltalk-80. Journal of Object- Oriented Programming (pp. 26-49). SIGS Publication. 
Kristanto, A. (2003). Perancangan Sistem Informasi. Yogyakarta: Gava Media. Land, R. (2002). Measurements of Software Maintainability.

Leff, A., \& Rayfield, J. T. (2001). WebApplication Development Using the Model/View/Controller Design Pattern. Enterprise Distributed Object Computing Conference, 2001. EDOC '01. Proceedings. Fifth IEEE International, (pp. 118-127). Seattle, WA.

Lewis, J. R. (1993). IBM Computer Usability Satisfaction Questionnaires: Psychometric Evaluation and Instructions for Use. Boca Raton: IBM Corporation.

McCall, J. A., Richards, P. K., \& Walters, G. F. (1977). Factors in Software Quality. US Rome Air Development Center Reports.

Nielsen, J. (2003). Introduction to Usability. Retrieved Januari 1, 2012 , from http://www.useit.com/alertbox/2 0030825.html

Paikens, A., \& Arnicans, G. (2008). Use of Design Patterns in PHPBased Web Application Frameworks. Department of Computing University of Latvia.

Shan, T. C., \& Hua, W. W. (2006). Taxonomy of Java Web Applications Frameworks. IEEE International Conference on $e$ Business

Engineering
(ICEBE'06).

Spinellis, D. D. (2006). Code Quality: The Open Source Perspective. Boston: Addison-Wesley.

Subraya, B. M. (2006). Integrated Approach to Web Performance Testing: A Practitioner's Guide. Idea Group Inc.

Sugiyono. (2010). Metode Penelitian Kuantitatif Kualitatif dan $R \& D$. Bandung: Alfabeta.

Sukmadinata, N. S. (2010). Metode Penelitian Pendidikan. Bandung: Remaja Rosdakarya.

Supaartagorn, C. (2011). PHP Framework For Database Management Based On MVC Pattern. International Journal of Computer Science \& Information Technology (IJCSIT) Vol 3 No 2, 251-258.

Sutanta, E. (2011). Basis Data Dalam Tinjauan Konseptual. Yogyakarta: ANDI.

Upton, D. (2007). CodeIgniter for Rapid PHP Application Development. Birmingham: Packt Publishing.

Woojong, S. (2005). Web Engineering: Principles and Techniques. USA: Idea Group Publishing.

Yahoo Developer Network. (2011). Best Practices for Speeding Up Your Web Site. Retrieved Januari 5, 2012 , from http://developer.yahoo.com/perfo rmance/rules.html 
Yicheng, L. (2011). Development of a Blog System Using CodeIgniter Framework. Finland: Oulu University of Applied Sciences.

Zyrmiak, D. (2001). Software Quality Function Deployment. Retrieved Januari 5, 2012, from http://www.isixsigma.com/toolstemplates/qfd-house-ofquality/software-qualityfunction-deployment/ 